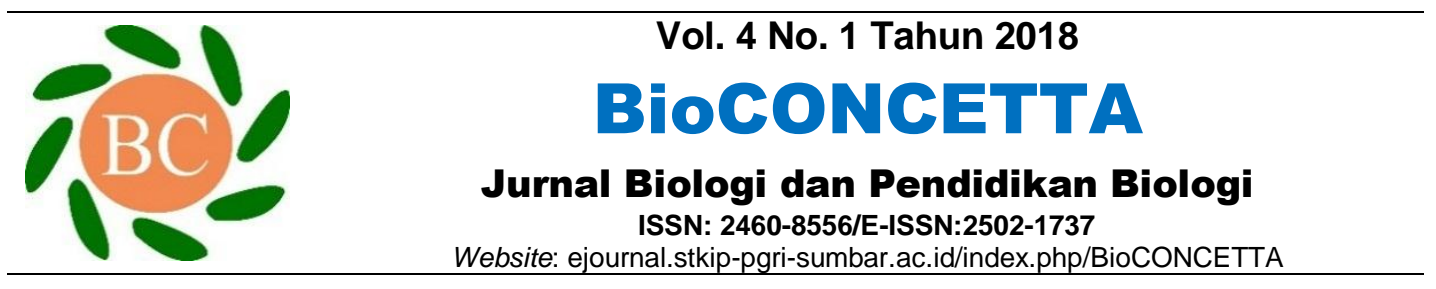

\title{
Pengaruh Penerapan Model Pembelajaran Problem-Based Learning Terhadap Aktifitas Siswa
}

Mimin Mardhiah Zural* dan Rahmayudi Febrinaldi Program Studi Pendidikan Biologi STKIP PGRI Sumatera Barat Jl. Gunung Pangilun Padang, Sumatera Barat (25137), Indonesia Email:miminzural@gmail.com

\section{Info Artikel}

Sejarah Artikel

Diterima:

13 Agustus 2018

Disetujui:

30 Agustus 2018

Dipublikasikan:

31 Agustus 2018

Kata Kunci:

problem-based

learning, ranah

afektif

Keywords: problem-based learning, affective domain

\begin{abstract}
Abstrak
Tujuan penelitian ini adalah untuk mengetahui bagaimana pengaruh penerapan model problem based learning terhadap aktivitas siswa kelas X di salah satu SMA di Indonesia. Jenis penelitian adalah eksperimen dengan partisipan semua siswa kelas X. Teknik pengambilan sampel dengan desain randomized posttest only control group. Sampel adalah siswa kelas X IPA3 sebagai eksperimen dan siswa kelas X IPA2 sebagai kontrol dan data dianalisis menggunakan t-test. Intrumen dalam penelitian ini adalah kuisioner sikap dengan skala pengukuran dan diolah dengan rumus persentase, maka diperoleh nilai siswa kelas eksperimen 83,56 dan siswa kelas kontrol 83,49 . Nilai yang diperoleh kemudian diuji statistik dengan t-test. Didapatkan $\mathrm{t}_{\text {hitung }}=0,27<\mathrm{t}_{\text {tabel }}=1,67$ sehingga $\mathrm{H}_{1}$ ditolak. Berdasarkan analisis data, dapat disimpulkan bahwa penerapan model pembelajaran problem based learning tidak memiliki pengaruh yang baik terhadap pembelajaran di ranah afektif.
\end{abstract}

\begin{abstract}
The aim of this research was to determine how the effect of the application of problem-based learning models on the activities of the student in grade $X$ in one of the high schools in Indonesia. The types of research is an experiment with participants of all student atgrade $X$. The sampling technique is a randomized posttest-only control group design. The sample was the students of class X IPA3 as an experiment and the students of class X IPA2 as controls and data were analyzed using a t-test. The instrument in this study is an attitude questionnaire with a measurement scale and processed by a percentage formula, then obtained the experimental students' is 83.56 and control students is 83.49. The value obtained is then tested statistically with T-test. Where $t_{\text {count }}=0.27<t_{\text {table }}=1.67$ so the hypothesis is rejected $\left(H_{l}\right)$. Based on data analysis, it can be concluded that the application of the problem-based learning model does not have a good influence on learning in the affective domain.
\end{abstract}




\section{PENDAHULUAN}

Pada proses pembelajaran terjadi proses interaksi antara guru dengan siswa. Dalam interaksi tersebut guru tidak hanya berperan sebagai pengajar, akan tetapi juga sebagai pendidik supaya siswa dapat aktif dalam proses pembelajaran. Untuk mencapai keberhasil dalam proses pembelajaran tentunya guru memerlukan suatu strategi agar tujuan pembelajaran yang telah dirancang dapat tercapai, baik menerapkan metode, pendekatan pembelajaran dan model pembelajaran yang bervariasi, dimana Rusman (2012:5) telah menyatakan bahwa belajar dapat dipandang sebagai proses yang diarahkan kepada tujuan dan proses berbuat melalui berbagai pengalaman belajar yang dirancang dan dipersiapkan oleh guru.

Proses pembelajaran yang kurang bervariasi dapat menimbulkan kebosanan terhadap siswa yang akan mengakibatkan berkurangnya perhatian, motivasi, dan minat siswa terhadap pelajaran, belajar dan guru yang akhirnya bisa berdampak pada hasil belajar. Asumsi ini telah dipertegas dengan rendahnya hasil belajar yang dicapai siswa akibat pola mengajar tidak variatif pada salah satu
SMA di Pasaman yang merupakan salah satu Kabupaten di Indonesia yang kurang dari KKM yang telah ditetapkan sekolah tersebut, dimana hasil belajar yang didata pada materi virus tersebut ditemukan dari 30 jumlah orang siswa pada kelas $\mathrm{X}$ yang tuntas adalah kelas X1: $51 \%, \mathrm{X} 2$ : 53\% X3: $63 \%, \mathrm{X} 4: 42 \%$ X5: $50 \%$. Padahal persentase ketuntasan yang ditetapkan sekolah masih kurang dari 80, yaitu $75 \%$ dari ketuntasan hasil belajar klasikal.

Maka untuk itu perlu adanya perubahan strategi untuk menciptakan suasana baru dengan adanya penerapan model pembelajaran dalam proses pembelajaran yang dilaksanakan, agar pembelajaran menjadi lebih bermakna dan lebih berkualitas. Hal ini juga disetujui oleh Latipah (2017: 172) dimana untuk menimbulkan motivasi belajar siswa, dengan mengenalkan hal-hal baru akan menimbulkan minat pada diri siswa. Oleh sebab itu guru perlu mengenalkan hal-hal baru dalam pengajarannya.

Model yang dipilih untuk pembelajaran adalah model pembelajaran yang mengaktifkan siswa dimulai dari sikap siswa selama 
proses pembelajaran, dimana siswa akan diarahkan untuk mencari, bertanya, menjawab, berdiskusi dan berbagi. Dengan dengan adanya pola sikap yang aktif diharapkan mampu mengubah hasil belajar. Banyak berbuat dalam belajar bagaimanapun juga akan lebih membangkitkan semangat dibandingkan dengan mendengarkan. Maka model problembased learning dianggap cocok untuk mengaktifkan siswa karena pembelajaran ini penyampaiannya dilakukan dengan cara menyajikan suatu permasalahan yang nyata, mengajukan pertanyaan-pertanyaan, memfasilitasi penyelidikan dan membuka dialog. Dalam pembelajaran berbasis masalah ini Nurdin dan Adriantoni (2016: 226) mengatakan siswa dalam pembelajaran berfungsi sebagai problem solver, dimana siswa sebagai peserta aktif, terlibat langsung dalam pembelajaran dan membangun pembelajaran. Salah satu contoh bahwa penerapan problem-based learning baik untuk meningkatkan aktivitas siswa dalam pembelajaran telah dibuktikan oleh Abdurrozak dkk., (2016: 879) dimana, terdapat faktor-faktor pendukung dalam meningkatkan kemampuan berpikir kreatif siswa, diantaranya adalah siswa berdiskusi dengan baik, kegiatan pembelajaran yang menyenangkan, siswa aktif dalam melaksanakan pembelajaran.

Dalam proses pembelajaran problem-based learning supaya siswa terdorong dan bergerak untuk aktif harus ada peran guru selain fasilitator, yaitu harus menjadi motivator yang baik untuk menciptakan suasana belajar yang aktif. Tugas ini telah dilaksanakan oleh Pelawi dan Sinulingga (2016: 37) dalam penelitiannya dalam penerapan model problem-based learning, dimana agar pembelajaran lebih optimal, guru menjelaskan kembali tujuan dari pelaksanaan problem-based learning, dan aktivitas-aktivitas yangakan dilaksanakan oleh guru dan siswa. Untuk menghindari siswa yang pasif, maka guru mendorong masing-masing ketua kelompok untuk selalu melibatkan anggota kelompoknya dalam setiap tahapan pembelajaran. Untuk mendorong siswa yang masih pasif dalam pembelajaran dan presentasi, maka guru menunjuk siswa pada masing-masing kelompok untuk menjadi presenter utama dalam presentasi berikutnya agar semua 
siswa turut berperan dalam penyajian hasil eksperimen.

Noviar dan Hastuti (2015: 46) juga telah membuktikan penerapan problem-based learning pada materi Avetebrata di kelas X SMA dimana penggunaan model problem-based learning berbasis scientific approach membuat hasil belajar ranah afektif kelas eksperimen lebih tinggi daripada kelas kontrol. Hal tersebut disebabkan model problem-based learning menjadikan siswa sebagai produsen pengetahuan yang membuat siswa memperoleh pengetahuannya berdasarkan penemuan sendiri bersama kelompoknya.

Berdasarkan uraian tersebut, maka tujuan dari penelitian ini adalah untuk mengetahui pengaruh penerapan problem-based learning kepada siswa kelas X SMA terhadap hasil belajar ranah afektif yang dilaksanakan pada materi Virus.

\section{BAHAN DAN METODE}

Penelitian ini telah dilaksanakan pada Bulan Juli Tahun Ajaran 2017/2018 pada siswa Kelas X SMAN I Tigo Nagari Kabupaten Pasaman. Jenis penelitian ini adalah penelitian eksperimen yang diujikan pada materi Virus. Untuk menentukan kelas sampel digunakan desain randomized posttest only control group, yaitu dengan mencari nilai rata-rata hasil belajar ulangan harian siswa sebelum masuk pertemuan materi Virus. Nilai rata-rata yang dijadikan sampel adalah nilai yang sama atau yang mendekati. Penentuan siswa kelas eksperimen dan siswa kelas kontrol dengan cara mencabut undian. Sampel yang terpilih dalam penelitian ini yaitu siswa pada kelas X IPA 3 (kelas eksperimen) dan siswa kelas X IPA 2 (kelas kontrol). Instrumen yang digunakan dalam penelitian adalah kuisioner sikap belajar siswa yang dinilai oleh observer pada saat proses pembelajaran berlangsung. Aspek yang dinilai yaitu kerjasama, bertanggung jawab dan responsif. Setiap aspek terbagi dalam 3 aktivitas.

Dalam penelitian ini rumus yang digunakan adalah rumus persentase, yaitu (skor yang diperoleh/skor maksimal) x 100\%, dengan kriteria Sangat Baik (86-100), Baik (71-85), Cukup (56-70) dan Kurang $(\leq 55)$ (Permendikbud No. 53, 2015:45). Hasil belajar yang didapat kemudian diuji statistik, yaitu; uji normalitas dengan menggunakan rumus Liliefors, uji homogenitas dengan uji $\mathrm{F}$ dan 
hipotesisnya dengan uji $\mathrm{t}$ untuk diuji statistik ditampilkan pada Tabel mengetahui apakah model 1.

pembelajaran yang diterapkan

Pada masing-masing aspek memberikan pengaruh terhadap hasil pengamatan didapatkan nilai rata-rata belajar ranah afektif.

\section{HASIL DAN PEMBAHASAN}

Hasil penilaian ranah afektif yang diperoleh melalui observasi sikap yang dilakukan siswa didapatkan nilai indikator kerjasama, bertanggungjawab dan responsif seperti yang dideskripsikan pada Gambar 1, kemudian nilai indikator yang telah ranah afektif pada aspek kerjasama siswa kelas kontrol lebih tinggi daripada siswa kelas ekperimen tapi masih pada prediket sangat baik (A). Pada aspek bertanggung jawab dan aspek responsif pada siswa kelas eksperimen lebih tinggi daripada siswa kelas kontrol tapi juga masih berada dalam prediket yang sama yaitu baik (B) (Gambar 1).

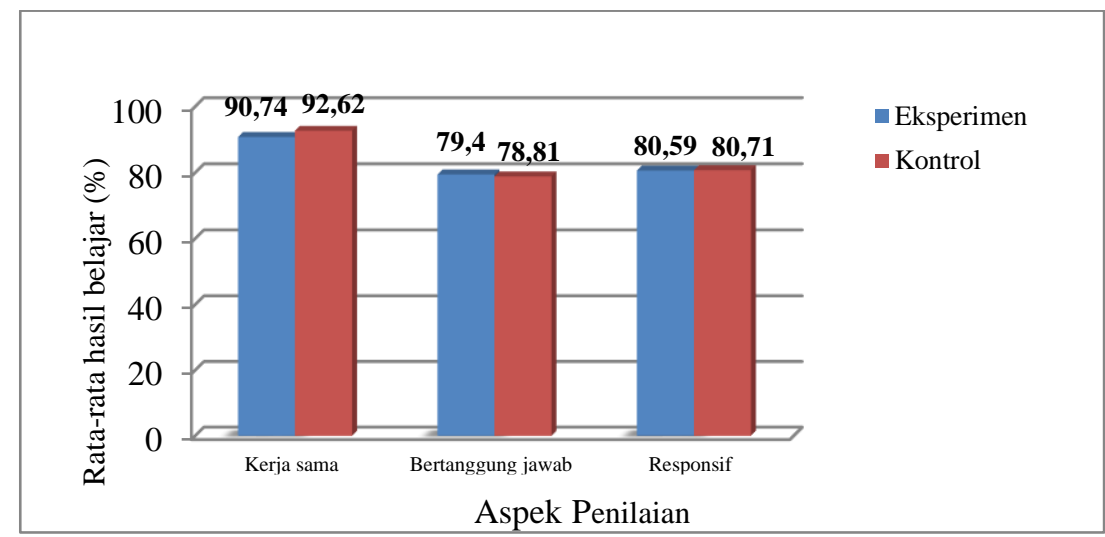

Gambar 1. Nilai rata-rata ranah afektif pada kelas eksperimen dan kontrol.

Tabel 1. Uji Statistik Hasil belajar Ranah Afektif

\begin{tabular}{llc}
\hline Uji Statistik & \multicolumn{1}{c}{ Hasil } & Jawaban \\
\hline Normalitas & Ekspreimen: $\mathrm{L}_{0}=0,0406<\mathrm{L}_{\text {tabel }}=0,1417$ & Berdistribusi \\
& Kontrol: $\mathrm{L}_{0}=0,0793<\mathrm{L}_{\text {tabel }}=0,1497$ & normal \\
Homogenitas & $\mathrm{F}_{\text {hitung }}=1,84<\mathrm{F}_{\text {tabel }}=0,9807$ pada taraf nyata 0,05 & Varian homogen \\
& dengan dk 35,34 & \\
Hipotesis & $\mathrm{T}_{\text {hitung }}=0,027<\mathrm{t}_{\text {tabel }}=1,67$ & Hipotesis ditolak \\
\hline
\end{tabular}

Pada masing-masing aspek ranah afektif pada aspek kerjasama pengamatan didapatkan nilai rata-rata siswa kelas kontrol lebih tinggi 
daripada siswa kelas ekperimen tapi masih pada prediket sangat baik (A). Pada aspek bertanggung jawab dan aspek responsif pada siswa kelas eksperimen lebih tinggi daripada siswa kelas kontrol tapi juga masih berada dalam prediket yang sama yaitu baik (B) (Gambar 1).

Data hasil belajar ranah afektif tersebut kemudian diuji statistik untuk mengetahui pengaruh penerapan problem based learning terhadap siswa. Data uji normalitas kelas ekperimen diperoleh $\mathrm{L}_{0}<\mathrm{L}_{\text {tabel }}$ (Tabel 1), dengan demikian hasil belajar siswa berdistribusi normal. Uji normalitas kelas kontrol juga diperoleh $\mathrm{L}_{0}<\mathrm{L}_{\text {tabel }}$ (Tabel 1), dengan demikian hasil belajar siswa berdistribusi normal.

Karena kedua kelas sampel berdistribusi normal, maka dilakukan uji homogenitas dengan hasil uji
$F_{\text {hitung }}<\mathrm{F}_{\text {tabel }}$ maka kedua kelas sampel mempunyai varian yang homogen maka dilakukan uji t pada taraf 0,05, dimana $\mathrm{T}_{\text {hitung }}<\mathrm{T}_{\text {tabel }}$, dengan demikian hipotesis ditolak. Ini berarti penerapan model pembelajaran problem-based learning kepada siswa tidak memberikan pengaruh terhadap hasil belajar ranah afektif. Berikut dibahas berdasarkan indikator pengamatan.

Aspek kerjasama untuk setiap pertemuan pada siswa kelas eksperimen dan siswa kelas kontrol sama-sama memiliki predikat sangat baik (A), dimana penilaian rata-rata keseluruhan aspek kerjasama dapat dilihat pada Gambar 1. Jabaran penilaian aspek kerjasama setiap pertemuan pembelajaran dengan perolehan nilai setiap pertemuan seperti yang dideskripsikan pada Gambar 2.

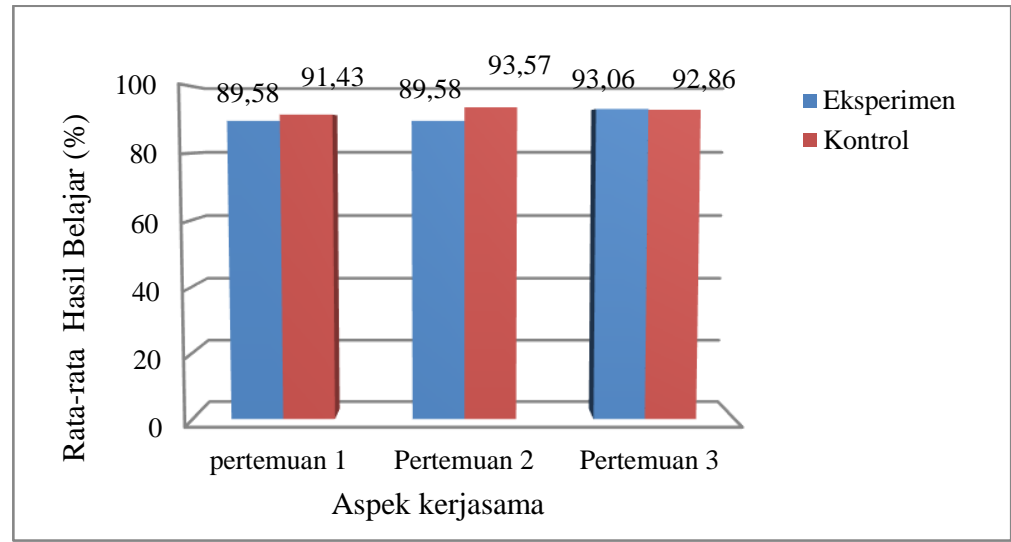

Gambar 2. Nilai rata-rata aspek sikap kerjasama siswa kelas eksperimen dan kontrol. 
Aspek kerjasama siswa kelas eksperimen dan siswa kelas kontrol terlihat pada saat siswa ikut berdiskusi dalam kelompok, siswa ikut menyampaikan saran/pendapat dalam kelompok, dan siswa berpartisipasi dalam membuat laporan hasil diskusi. Pada siswa kelas eksperimen dan siswa kelas kontrol sudah memperlihatkan keikutsertaan dalam berdiskusi, menyampaikan saran/pendapat dan berpartisipasi dalam membuat laporan hasil diskusi, hanya beberapa dari jumlah siswa yang tidak ikut berpartisipasi dalam membuat laporan hasil diskusi kelompoknya. Prediket sangat baik ini karena juga ditunjang oleh siswa yang belajar pada kedua kelas sampel samasama menggunakan cara belajar saintifik. Kemudian guru juga telah menjadi motivator yang baik untuk siswanya agar andil dalam setiap langkah-langkah pembelajaran baik dari penggunaan model problem-based learning pada siswa kelas eksperimen dan saintifik pada siswa kelas kontrol. Andil guru sebagai motivator mempunyai pengaruh yang besar dalam proses pembelajaran.

Pada pertemuan pertama dan kedua, dapat dilihat pada Gambar 2, bahwa diagram batang hasil belajar siswa kelas eksperimen tidak begitu memberikan hasil yang memuaskan dibandingkan kontrol. Ini dikarenakan siswa kelas eksperimen beradaptasi dengan model problem-based learning. Siswa dihadapkan pada masalah nyata dan sibuk sendiri mencari bagaimana cara mengumpulkan data, sehingga kerjasama siswa kelas eksprimen tidak menampak hasil tinggi dari nilai siswa kelas kontrol. Tapi pada pertemuan ketiga, dapat dilihat pada Gambar 2 tersebut, siswa mulai menampakkan kerjasama yang baik $(93,06)$ dan melebihi nilai yang didapatkan pada siswa kelas kontrol $(92,86)$ walaupun tidak begitu tinggi. Hal ini sudah memberikan nilai yang positif terhadap hasil belajarnya walaupun tidak dipandang berbeda dari segi uji statistik. Jadi perlu dipertimbangkan penerapan problem-based learning ini pada proses pembelajaran.

Harnitayasri dkk., (2015: 106) telah membuktikan model problembased learning membuat aktivitas diskusi lebih menarik dari diskusi biasanya, sehingga aktivitas siswa dikatakan aktif saat siswa telah melaksanakan fase-fase dalam 
kegiatan pembelajaran, yang dimaksud disini adalah membuat rumusan masalah berdasarkan topik pembelajaran, mengorganisasikan tugas yang berhubungan dengan masalah yang telah ditetapkan sebelumnya, mengumpulkan informasi yang sesuai dengan topik permasalahan yang dibahas.

Hasil perolehan nilai aspek bertanggung jawab siswa pada setiap pertemuan digambarkan pada grafik batang yang ada pada Gambar 3 . Secara keseluruhan, penilaian aspek bertanggung jawab siswa kelas eksperimen dan kontrol sama-sama memiliki predikat baik (B), dimana penilaian rata-rata keseluruhan aspek bertanggung jawab dapat dilihat pada Gambar 1.

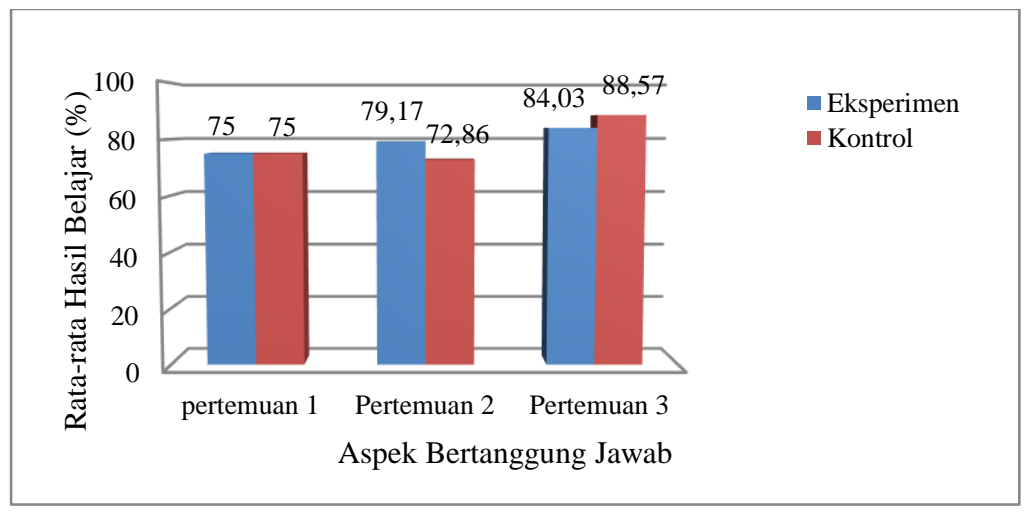

Gambar 3. Nilai rata-rata aspek sikap bertanggung jawab kelas eksperimen dan kontrol

Nilai rata-rata siswa di kelas eksperimen untuk sikap bertanggung jawab untuk mengerjakan dan menyelesaikan tugas yang diberikan guru sesuai dengan tujuan pembelajaran mendapatkan nilai $79,4 \%$. Sedangkan pada kelas kontrol siswa sudah menunjukkan sikap bertanggung jawab dalam mengerjakan dan menyelesaikan tugas yang diberikan guru sesuai dengan tujuan pembelajaran dengan nilai rata-rata $78,81 \%$. Nilai aspek bertanggung jawab ini tidak memiliki perbedaan yang begitu berarti pada siswa kelas eksperimen dan kontrol, karena kegiatan untuk mengerjakan dan menyelesaikan tugas dikontrol oleh guru agar semua siswa ikut berpartisipasi. Menurut Asma (2012: 
9-10) setiap anggota kelompok memiliki predikat baik (B) yaitu bertanggungjawab untuk menguasai dengan nilai rata-rata siswa kelas materi pelajaran karena keberhasilan kelompok dinilai dari seberapa besar sumbangan hasil perorangan. eksperimen $80,59 \%$ dan siswa kelas kontrol 80,71\% seperti pada Gambar 4.

Pada aspek responsif siswa kelas eksperimen dan kelas kontrol

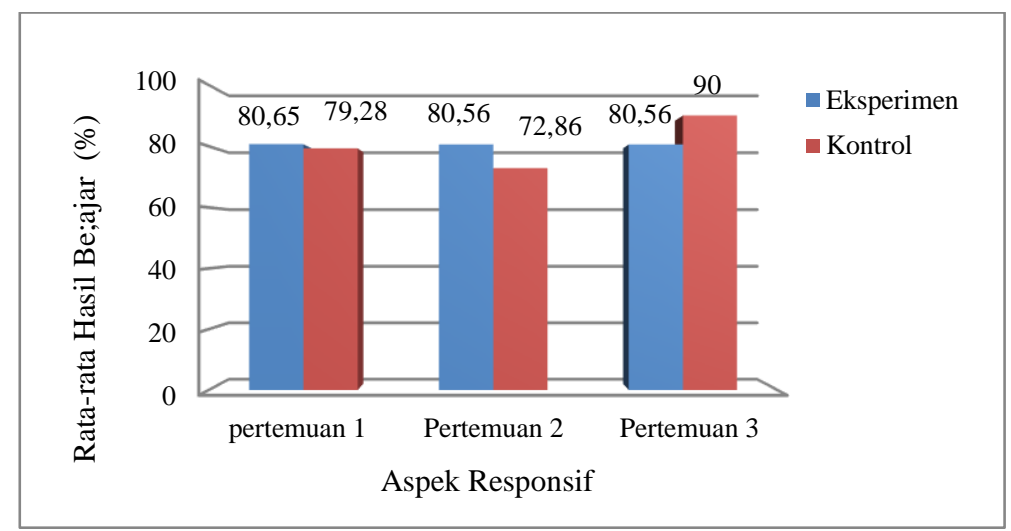

Gambar 4. Nilai rata-rata sikap responsif siswa kelas eksperimen dan kontrol.

Aspek sikap responsif siswa kelas eksperimen pada pertemuan pertama terlihat bahwa siswa telah memperlihatkan sikap responsif atas pertanyaan, jawaban dan ulasan temannya. Interaksi siswa dengan siswa dalam proses pembelajaran, siswa terlihat membuat keributan didalam kelas karena timbulnya beberapa beda pendapat, selisih paham dan berdebatan mengenai jawaban yang didapat dalam kelompok masingmasing. Tapi sikap yang muncul ini bersifat positif karena siswa bersifat respon terhadap teman-teman dalam kelompoknya. Debat bukan berarti hal buruk dan tidak menghargai pendapat teman. Debat siswa-siswa tersebut adalah untuk mempertahankan sesuatu yang diyakini benar dengan bukti yang telah ada didapati siswa tersebut.

Pada pertemuan kedua, siswa kelas eksperimen mulai aktif mengemukakan idenya pada saat proses diskusi, masing-masing anggota kelompok sudah mulai ikut berpartisipasi dalam mengumpulkan data/informasi/jawaban dari tugas yang diberikan oleh guru. Pada pertemuan ketiga, adaptasi siswa kelas 
eksperimen dengan model pembelajaran yang diterapkan guru sudah nampak dengan baik, sehingga tidak perlu banyak komando guru untuk siswa mengikuti langkah problem-based learning. Pada saat diskusi siswa sudah aktif menyampaikan ide/gagasan tentang materi yang disampaikan, ini terlihat ketika siswa bertanya dan berdiskusi dalam kelompok, akan tetapi pertanyaan yang diajukan pada saat diskusi sama dengan kelompok lain yang sudah ditanyakan sebelumnya, sehingga terkesan siswa tersebut kurang menyimak terhadap pertanyaan-pertanyaan yang sudah disampaikan. Sikap responsif siswa pada saat kelompok lain presentasi dari pertemuan 1 sampai dengan pertemuan 3 belum menampakkan nilai yang baik, karena masih banyak siswa yang kurang memperhatikan kelompok lain yng tampil saat mempresentasikan hasil diskusi dan sibuk dengan tugas yang belum selesai. Ini salah satu faktor yang mendukung nilai responsif siswa kelas eksperimen (Gambar 4).

Komunikasi antara teman dalam kelompok dan antara siswa dengan guru sudah terjalin dengan baik. Tapi permasalahannya adalah belum terjalinnya sikap komunikasi yang responsif dengan kelompok lain. Hal ini didukung oleh Wulandari dkk., (2018:54) bahwa pada penerapan pembelajaran dengan model pembelajaran problem-based learning terjadi komunikasi aktif antara guru dengan siswa, siswa dengan siswa dalam berdiskusi dan bertukar pendapat. Tapi pendapat Wulandari dkk., (2018:54) mengenai aktifnyasiswa mengkomunikasikan hasil dari diskusi, ini belum mampu menarik perhatian siswa kelas eksperimen untuk merespon kelompok lain untuk masuk dalam area diskusi klasikal. Hal ini dikarenakan alasan yang sudah dikemukakan sebelumnya, yaitu siswa-siswa dalam kelompok masih terfokus untuk menyelesaikan tugas yang diberikan oleh guru. Lamanya waktu yang dibutuhkan siswa dalam menyelesaikan tugas menjadi alasan siswa untuk tidak merespon presentasi kelompok lain. Apalagi permasalahan yang harus dituntaskan siswa bermula pada tahap orientasi siswa pada masalah nyata yang ada, dimana masalah ini menantang pengetahuan yang dimiliki siswa. Kemudian siswa diarahkan 
untuk mencapai tujuan pembelajarannya berdasarkan rumusan masalah yang sudah dibuat. Jadi siswa mengumpulkan datanya dari berbagai sumber yang disediakan atau yang tidak disediakan. Tidak seperti siswa kelas kontrol yang menyelesaikan langkah-langkah ilmiahnya berdasarkan permasalahan yang mereka temukan sendiri, yang jawabannya sudah tersedia dalam buku sumber yang mereka gunakan. Ini sesuai dengan yang diungkapkan oleh Nurdin dan Adriantoni (2016: 228) kekurangan pembelajaran berbasis masalah dalam pemanfaatannya adalah kurangnya waktu pembelajaran. Kekurangan yang dikemukakan tersebut ini menjadi kekurangan yang tidak bisa dipungkiri karena memang waktu untuk tatap muka dengan siswa hanya 2x45 menit, sementara siswa harus menuntaskan semua tugas pembelajaran yang diberikan sesuai dengan langkah-langkah problembased learning.

Tapi dalam hal segi motivasi, siswa kelas eksperimen mempunyai motivasi yang tinggi menyelesaikan tugas yang diberikan. Karena jika dilihat dalam kecepatannya dalam menyelesaikan tugas, maka siswa kelas intrumen membutuhkan waktu yang sama dengan siswa kelas kontrol dengan permasalahan tugas yang lebih kompleks dari kelas kontrol. Ini didukung oleh Herlina dkk., (2016:16), dimana motivasi berprestasi tinggi selalu berkeinginan untuk menyelesaikan sesuatu untuk mencapai standar kesuksesan. Siswa yang memiliki motivasi berprestasi tinggi akan memiliki keinginan yang kuat dalam meraih hasil belajar sampai mencapai kesuksesan yang diinginkan. Karena aspek yang diamati ini dilihat dari segi responsif siswa, bisa diketahui apa yang menyebabkan nilai responsif tersebut rendah.

Berdasarkan alasan-alasan yang dikemukakan dari hasil pembelajaran ranah afektif yang didapat dalam proses pembalajaran, hal inilah yang mengakibatkan kenapa penilaian pada ranah afektif tidak mengalami peningkatan pada siswa kelas eksperimen walaupun telah diterapkan model pembelajaran problem-based learning.

\section{SIMPULAN}

Berdasarkan hasil penelitian yang telah dilakukan, maka dapat disimpulkan bahwa penerapan problem-based learning pada siswa 
tidak meningkatkan aktivitas siswa dalam belajar.

\section{DAFTAR PUSTAKA}

Abdurrozak R, Asep KJ, dan Isrok A. 2016 . Pengaruh Model Problem Based Learning Terhadap Kemampuan Berpikir Kreatif Siswa. Jurnal Pena Ilmiah 1 (1) Hal: 871-880

Asma, Nur. 2012. Model pembelajaran kooperatif. Padang: Universitas Negeri Padang.

Harnitayasri, Nurhayati dan Irma S. 2015. Efektivitas Model Pembelajaran Problem Based Learning (PBL) Terhadap Hasil Belajar Biologi Siswa pada Materi Pencemaran Lingkungan di Kelas X SMA Negeri 2 Polewali. Jurnal Bionature. 16 (2) Hal: 103-109.

Herlina, Amiruddin K., dan Hartono DM. 2016. Pengaruh Model Problem Based Learning dan Motivasi Berprestasi Terhadap Hasil Belajar Siswa pada Mata Pelajaran BiologI di Kelas XI IPA MAN 2 Model Palu. Jurnal Sains dan Teknologi Tadulako. 5 (1) Hal: 11-16.
Latipah, E. 2017. Psikologi Dasar Bagi Guru. Bandung: Remaja Rosdakarya

Noviar D dan Dwi RH. 2015. Pengaruh Model Problem Based Learning (PBL) Berbasis Scientific Approach terhadap Hasil Belajar Biologi Siswa Kelas $\mathrm{X}$ Di SMA N 2 Banguntapan T.A. 2014 / 2015. Bioedukasi. 8 (2). Hal: 42-47

Nurdin, S., dan Adriantoni. 2016. Kurikulum dan Pembelajaran.Jakarta: Rajawali Pers.

Rusman. 2012. Model-Model Pembelajaranan. Jakarta. Rajawali Perss.

Pelawi HS., dan Karya S. 2016. Pengaruh Model Problem Based Learning Dan Motivasi Belajar Terhadap Hasil Belajar Siswa Di Kelas X Sma Swasta Sinar Husni. Jurnal Pendidikan Fisika. 5 (1) Hal: 32-37.

Wulandari, NI., Astuti W., dan Widodo B. 2018. Efektivitas Model Pembelajaran Problem Based Learning Terhadap Hasil Belajar IPA Ditinjau dari Kemampuan Berkomunikasi Siswa. J.Pijar MIPA XIII (1) Hal: 51-55. 